\title{
Engendering energy in Ethiopia: The role of solar energy in improving rural women's socio-economic conditions in Tigrai Region
}

\author{
Gebrecherkos Gebregiorgis \\ Mekelle University (Public University), Ethiopia. \\ Received 23 April 2014; Accepted 9 January 2015
}

\begin{abstract}
This study was conducted on the role of solar energy in improving the socio-economic conditions of women in Tigrai region, Ethiopia. The specific objectives of the study were to assess the extent of solar energy use, to examine the role of solar energy in promoting women's income earning strategies and access to social services; to document the perceptions and attitudes of women beneficiaries towards solar energy interventions and assess the challenges and prospects. The study employed both quantitative and qualitative research methods (mainly surveys and ethnography). Primary data were gathered from different sources including beneficiary women household heads, local residents and pertinent administrative bodies. The specific tools for primary data collection include household questionnaires, semi-structured interviews with key informants, focus group discussions, and in-depth interviewing. The study also made use of secondary data obtained from reports and various documents. Primary data were analyzed using descriptive statistics including tables, charts and percentages using appropriate software. Qualitative data were presented in narrative descriptions while the results of the case studies were presented in the form of illustrative boxes to substantiate and consolidate major quantitative findings. The findings of the study indicate a substantial shift from biomass use to photovoltaic(PV) electricity which has improved women's access to income and social services: shops and cinema houses flourished; radio and TV sets could be used to obtain information; schools and health posts gave better services and the time and energy women spent fulfilling their traditional roles such as cooking was reduced allowing them to actively participate in development activities like soil and water conservation. Major constraints and challenges identified were mainly related to sustainability: problems associated with maintenance, inaccessibility of spare parts, lack of technical skill to operate the systems, lack of follow-ups from concerned bodies as well as financial constraints
\end{abstract}

Key words: Solar energy, socio-economic impacts, women, Tigrai, Ethiopia.

\section{INTRODUCTION}

Africa is often divided into three regions in terms of the energy source: North Africa which is rich in oil and gas, South Africa which relies on coal and the rest of the subSaharan region which heavily depends on traditional biomass energy derived from wood, charcoal, crop residue and animal by-products (Karekezi, 2002).
In sub-Saharan Africa, energy consumption is very low. Indeed, Sub-Saharan Africa is also one of the most disadvantaged regions in terms of per capita energy consumption which is far from adequate to put development activities on track and maintain a decent standard of living (ECA, 2002). According to World Bank 
(2003), the average per capita consumption of modern energy in eastern and southern Africa between years 1980 and 2000 ranged from 317 to $291 \mathrm{kgoe}$. In terms of electricity consumption, it is even more striking to note that the per capita electricity supply is very low often falling between 112 to 431 kwh kWh (World Bank, 2003, 2004).

Moreover, the overall energy demand of sub-Saharan Africa is estimated to be 267 Mtoe of which over $80 \%$ is derived from biomass, $27 \%$ from oil, $3 \%$ from hydropower and $2 \%$ from gas (World Bank, 2003). On the one hand, African countries spend much of the foreign exchange earnings to import petroleum products to satisfy an extremely limited proportion of the demand for energy $(E C A, 2002)$. On the other hand, the overwhelming dependence on biomass fuels created two types of problems: serious imbalances between supply and demand and a substantial loss of biodiversity and degradation of forest resources (ECA, 2002). As for the former, in the year 2000 alone, countries like Ethiopia Kenya, Malawi, Nigeria and Tanzania encountered enormous shortage of power supply that led to rationing which adversely affected not only households but also national economic performance of the countries (Karekezi and Afrepren, 2003). As for the latter, if unabated, such destructive trends will have far reaching negative consequences on agricultural production systems and environmental sustainability at large.

Those issues, together with recent global developments (e.g., the recent upsurge in the price of oil on world markets) gave rise to the importance of renewable energy in Africa. As known, Sub-Saharan Africa is rich in renewable energy sources. Yet, this potential has not been adequately exploited as a result of several hindrances related to inappropriate policy making, financial constraints, technical inadequacies, and low level of investments (Karekezi and Kithyoma, 2002).

In this context, women suffer most because of the physical and metaphorical burden of household energy provision as one of their fundamental responsibilities. In rural areas, women spend several hours a day fetching firewood often returning home with a load of $20 \mathrm{~kg}$ or more. In urban areas, women have to spare more time and energy dealing with organizing household income to provide charcoal and kerosene. Women often succumb to lung and eye diseases due to long hours of exposure to smoke in kitchens (Smith 1999, 2002). Fuel wood collection also prevents women from actively engaging in other income earning activities. In much of the developing world, women also shoulder other domestic responsibilities including fetching water and food processing which consume much of their time (Smith, 2002). Energy interventions are therefore key to reducing the drudgery in such laborious day-to-day activities.

Studies on solar energy utilization and dissemination in rural communities are numerous; however, differential gender impacts in particular have not been largely explored (Ward et al., 1984; Karekezi and Ranja, 1997). There have been discrete cases studies in few subSaharan countries such as Kenya (Mbuthi, 2003), Zimbabwe (Afrepren, 2001) and Botswana (Fagbenle, 2001) while not much is known about the situation in Ethiopia - a country which claims to have 13 months of sunshine. Against this background, the author set out to carry out a case study on the impact of solar energy on socio-economic conditions of women in rural Tigray (Ethiopia) with a conviction that such a study will serve as a spring board for further country or locality based case studies on differential gendered impacts renewable energy in other parts of Ethiopia or/and Africa.

\section{LITERATURE REVIEW}

\section{The gender-energy nexus in Africa}

In developing countries, the discourse on gender and energy revolves around the overall workload of women in domestic responsibilities associated with supporting the family, cooking food and collection of traditional fuel which not only consumes a large proportion of their time and energy but also makes them susceptible to other social and health problems (Clancy, 2002; Denton, 2002). Often, women's overwhelming roles in such domestic activities also undermine their productive roles in society. There is growing evidence indicating differential patterns of energy use by men and women in many countries (Annecke, 1999; Cecelski, 2004). According to such findings, women commonly used traditional fuel and energy-using subsistence tasks while men depended on more modern energy sources that could be traded for income and productive activities (Baguant and Manrakha 1994). As a result, interventions for provision of improved stoves and cooking appliances often target women beneficiaries in order to free them from the more laborious activities (Fagbenle, 2001; DFID, 2002).

Women shoulder the responsibility of supplying household energy but access to modern sources of energy including clean fuels and electricity affects both men and women (Farhar, 2000; Clancy, 2007). However, availability of energy has different impacts on men and women as they have different experiences with application of energy (Clancy and Skutsch, ND). Despite such trends, energy polices in many countries have adopted

E-mail: geb4002003@gmail.com

Author agree that this article remain permanently open access under the terms of the $\underline{C r e a t i v e ~ C o m m o n s}$ Attribution Lic ense 4.0 Intemational Lic ense 
gender-blind perspectives on issue of pricing, rural energy supply and technology use (Batliwala and Reddy 1996). Such policies often ignore gender based differences in the need prioritizations and assets. The lifting of subsidies on fossil fuels encourages the promotion of efficient energy, environmental rehabilitation, natural resource conservation (Burn and Coche 2001).

Studies on differential impacts of energy pricings policies on men and women have remained rare (Cecelski 2004). Nevertheless, it can be hypothesized that the price settings have not operated in favor of poor households and have had serious negative consequences including a downward transition in fuel quality and tendency of poor people to resort to illicit electricity connections (Andrade, 2004). As women shoulder the burden of household energy provision, they have to deal with inflating prices and consider this on already tight budget creating further pressures on poor women's economic conditions (Makan, 1995; Green, 2001).

The role of energy technologies on reducing domestic workload and improving productivity is now well recognized in developing countries but benefits are still not fairly distributed (Lambrou and Piana, 2007). For example, solar systems at home are better adapted to men's entertainment functions while they are less fit with women's needs for cooking (Menash, 2001; Denton, 2002).

According to Cecelski (2004), renewable energy technologies have a strong potential for tackling drudgery and income generation activities in rural areas. However, in order to ensure equal advantages of the system for both men and women, two major factors that often operate against the interest of the latter should be carefully addressed: credit facilities and access to technical skills, knowledge and information (ibid 2004).

The expanding scope of the concept of gender and energy fits with overall gender analysis in the context of development elsewhere (Green, 2001; Menash, 2001). In general previous discourses in gender and development also underscore the three types of women's needs: practical (aimed at ensuring survival), productive (related to income generation) and strategic (power and decisionmaking activities). All the three have an energy dimension: the practical dimension could be linked with household lights, improved technologies for cooking, etc., while the productive aspect may apply to income generation through electric sewing machines; the strategic component can be linked to women's increased freedom for movement after darkness falls (Menash 2001).

On the other hand, the Millennium Development Goals (MDGs) ratified by world leaders in 2000 did not place any specific targets on energy (World Bank, 2004). The relationship between genders as well as gender and development in general has been described only implicitly while other organizations such as the UK based Department for International Development (DFID 2002) have outlined the positive role energy plays in meeting such targets.
Access to energy enhances food production, employment and clean water supply thereby contributing positively towards poverty alleviation (Karekezi and Afrepren, 2003). However, access to clean energy has more benefit to women as it helps them save their time, and achieve improved health conditions (ibid 2003). Our understanding of energy and gender has significantly increased over the last couple of decades. In the past it was only associated with cooking and saving women from the toils of life (Clancy, 2002, 2007). Today, it has a broader scope of application to include all household activities and the linkages with other aspects of livelihood including agriculture, health, education and alternative sources of income (ibid 2002, 2007).

Much of the discussion on gender and energy has hitherto considered women in isolation as a result of the fact that over $70 \%$ of the world's 1.3 billion poor people are women and nearly a third of rural households are female headed (Clancy et al., 2004). Women, therefore find themselves at a disadvantaged position in terms of access to productive resources such as land, cash and credit(with low level of literacy and experience with technological hardware) and hence when making energy interventions for poverty reduction, the capabili-ties of women to respond to such intervention tends to be lower than that of men. Therefore, extra measures should be taken to include resource poor women into the benefit package. However, current trends also demonstrate that not only women but also men should be considered in household level decision making. Provision of energy can indirectly benefit men (eg. meals are prepared faster) while men can also a proactive and constructive role in the process of energy intervention as they are influential in shaping the outcomes of energy interventions (ibid2004).

\section{The status of solar energy and rural electrification in Ethiopia}

In Ethiopia, about $70-80 \%$ of the household energy supply comes from biomass although the demand for it is still higher than the supply. Often, there is no sustainable cultivation and efficient use of wood resources which results in deforestation, soil erosion and desertification (Heimann, 2009). Only 7-20\% of rural Ethiopia is believed to have access to electricity and most of the limited access to electricity in rural areas comes from diesel generators. In 2006, per capita energy consumption was approximately $32.94 \mathrm{kWh}$ which is extremely low; although energy consumption is showing steady increase in recent years (ibid 2009).

Solar energy is one of the potential sources of energy that can be used to operate lighting systems for households, heat water for cooking and irrigation systems in rural villages. According to a study (Heimann, 2009), the average daily solar radiation reaching the ground in 
Ethiopia amounts to $5.2 \mathrm{KWh} / \mathrm{m}^{2}$ which is one of the highest in the world in terms of strength. Nevertheless, solar energy technologies are unaffordable for the rural poor and the use of PV systems is limited to island net systems and is too weak to join the national grid system (ibid 2009). Solar thermal systems on the other hand are less expensive and can provide adequate energy for cooking which is an important area of need for many Ethiopians. The only limitation with such gadgets is that they need direct sun light and they can be used only when the sun is shining.

Target 2 of the Ethiopian Growth and Transformation Plan for 2011-2015 states "Introducing renewable sources of energy (solar, wind etc) to rural areas which are off grid rural electrification, making 14,700 households, 200 institutions of social services to use solar energy" (Tigrai Regional State, 2010). Similarly, Target 4 of the GTP also emphasizes "Protecting environmental pollutions by introducing different environmental tools, establishing and strengthening organizations, and adapting better or modern energy options." And Objective 4 of the document underscores the need for "developing resources of energy to improve the socioeconomic condition of our people" (ibid 2010).

Accordingly, efforts have hitherto been made to expand the energy sector of the country by focusing on renewable sources. Solar energy has been used to run solar pvs in schools, health centers, pumps for ground water, and telecommunication services (Tigrai Regional State, 2010). This sentence should be expanded adequately by giving detailed evidences in figures on the extent of solar PVS usage in the region.

Solar energy provision does not only provide electricity to rural households; but also affects the entire livelihood conditions of people (income, education, and health), gender, access to information and communication technologies as well as social issues, which are key to poverty alleviation. However, according to a recent study (Schutzeichel, 2012), the fundamental problems associated with low solar energy use and slow expansion of the sector in Ethiopia were found out to be lack of interest on the part of investors (local and foreign), government bureaucracy and constraints related rural customers' purchasing power (ibid 2012).

The research contributes to existing literature in the following ways: First and foremost, off-grid electricity supply in peripheral areas of Africa has not been properly addressed. Marginalized rural communities have been sidelined in terms of research and development and the current study is hoped to shed light on the agonies of such sidelined minorities that are desperate for attention of policy makers and researchers in developing communities. In light of the preoccupation of African governments on macro-issues of foreign direct investment and large scale industrial and agricultural transformation schemes, local efforts for socio-economic provisions are almost always off-scope. Secondly, the linkage between power supply and poverty reduction in Africa has hitherto not gained substantial attention and hence the required physical and financial resources have not been allotted to such an important sector. Thirdly, in studies where access to energy sources has been addressed as an important factor in national development, its direct and indirect connections to food security have never been underscored. Therefore, this study brings to the surface muffled voices of local communities in general and women in particular and analyzes the discourse in lowcost off-grid power supply and its socio-economic impacts on women: an issue that needs to be addressed with caution if sustainable development is to be achieved in third world countries like Ethiopia.

\section{Objectives}

\section{General objective}

The overall objective of the study was to assess the socio-economic impacts of solar energy on women in Tigrai region, Ethiopia.

\section{Specific Objectives}

The specific objectives of the study were:

1. To assess the extent of solar energy use in the selected study sites,

2. To examine the role of solar energy in promoting women's income earning strategies and access to social services;

3. To examine the perceptions and attitudes of women beneficiaries towards solar energy interventions

4. To examine the challenges and prospects of solar energy use by women

5. To suggest possible recommendation for future intervention on gendered impacts of solar energy and ensure its sustainability

\section{METHODOLOGY}

\section{Description of the study area}

Tigrai Region is one of the nine ethnic-based federal states found in the Northern tip of Ethiopia. It is inhabited predominantly by people who speak Tigrigna language which belongs to the Semitic linguistic group. Its capital city is called Mekelle and is located at a distance of $750 \mathrm{kms}$ north of Addis Ababa. Tigrai shares an international border with Eritrea to the north. It is also bordered by Gondar to the west, Afar region to the east, and Amhara region to the south west (CSA, 2008). The region covers an area of 50,078.64 square kilometers with a population size of 4.3 million of whom only $19.53 \%$ live in urban centers, while the rest (nearly $80 \%$ ) live in rural areas (ibid 2008). Subsistence agriculture is the mainstay of the economy and the environment is highly degraded with substantial loss in soil fertility as a result of shortage of rainfall, deforestation, poor technology and civil strife (Gebremedhin et al., 2002) (Figure 1). 


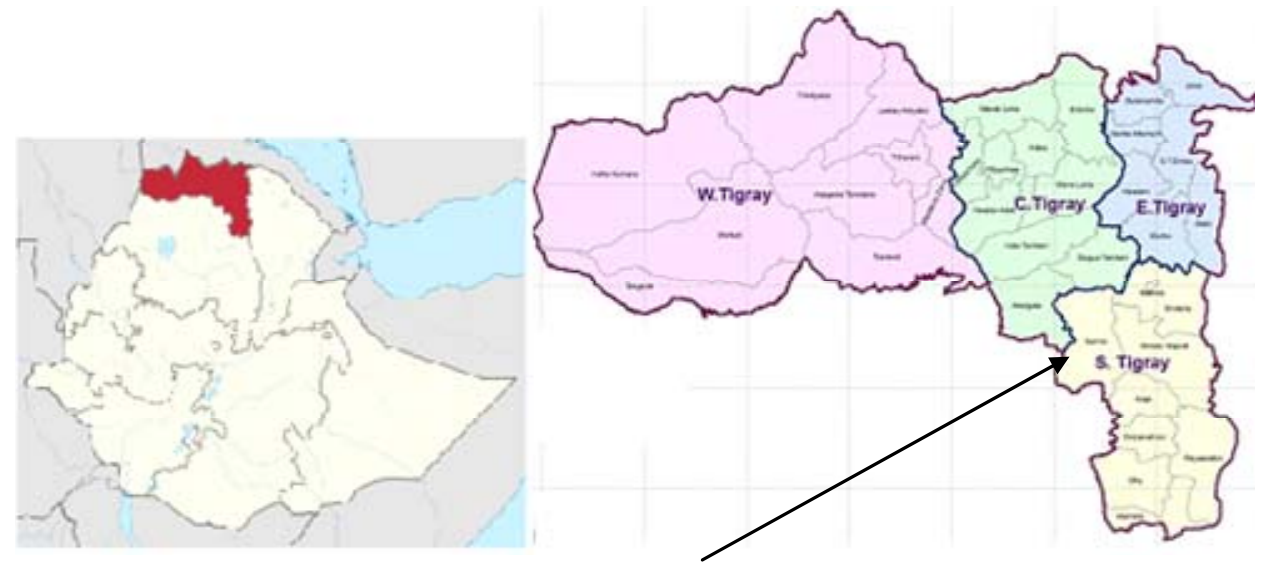

Figure 1. Map of Tigrai region and the study sites.

The study was conducted in Saharti Samre Wereda which is divided into 23 Tabias $^{i}$ with a total population of 124,340 , of whom only $7.39 \%$ live in urban centers. The Wereda covers an area of $2,723.89$ square kilometers. The area is characterized by the highly rugged terrains and it is one of the food insecure areas of the region. Rain-fed agriculture based on cereal production is the main source of livelihood although the people have experience in long distance migration as a means of earning livelihood.

\section{Sampling, type and sources of data, data collection and analysis}

The study was conducted in Samre Wereda. Samre Wereda was selected purposively because the area was identified as one of the prime intervention sites for off-grid energy supply in the region. The study was conducted with 120 households selected on the basis of random sampling. The study considered both women household members and heads of households and varying age categories (young and old).

Both primary and secondary data were collected from different sources both from the field and relevant organizations and offices. The primary data were gathered from women beneficiaries of solar energy appliances, non-beneficiaries, ordinary men and women residents of the specific study sites as well as local administrators and officials responsible for solar energy interventions particularly those engaged in the process of diffusion and adoption.

Both quantitative and qualitative research methods were used in the study. Quantitative data were gathered using household survey using questionnaire as a principal tooli. The questionnaire based study targeted beneficiaries of the solar energy technology in both the selected study sites.

On the other hand, qualitative data were collected with the help of a combination of PRA and ethnographic methods. The data collection process employed the following tools.

Focus-Group Discussions (FGDs): 8 FGDs were conducted with various groups of people including beneficiaries and nonbeneficiaries, local village residents, and administrative bodies. Focal groups were composed of 8-12 participants representing different sections of the communities (stratified based on age, gender and overall wealth category). The total time spent in each discussion varied from $1.5 \mathrm{~h}$ to nearly $2.5 \mathrm{~h}$.

Key Informant Interviews: 18 key informants (women residents and administrative authorities) were identified and approached for interviews. Selection of those informants was made based on information pertinent to their degree of experience with solar energy intervention, their knowledge and ability to explain developments related to women's conditions in the villages and their socialnetwork profiles.

Semi-structured Interviews: 26 women community members (13 from each Tabia) were also interviewed to obtain a wider perspective with regard to the diffusion and adoption of the solar energy technology, and the challenges and opportunities associated with it.

Personal Histories: In-depth interviewing was conducted with 9 women (6 beneficiaries and 3 non-beneficiaries) to obtain clear examples of how solar energy benefits women along with the household level challenges opportunities and prospects in the years to come.

Ranking exercises: women participants were also asked to put their problems and possible solutions and suggestions in accordance to their priority in order to determine areas of top concern for possible future interventions.

Observation: Observation was also employed to triangulate data obtained through other means. Often interview sessions were followed by visits to different locations in order to verify and crosscheck and see if there was a gap between what people said and what they do on the ground.

Quantitative data were analyzed using descriptive statistics including tables, charts, and percentiles. Appropriate software was used to manage data. This is augmented with findings of the qualitative data which is presented in descriptive form. Some case studies have been provided in order to illustrate major arguments.

\section{RESULTS AND DISCUSSION}

\section{Household characteristics of respondents}

\section{Age}

Since the study considered women beneficiaries only, $100 \%$ of the respondents were women. The bulk of respondents, i.e. 80 (nearly 66.7\%) fell within the age category of 20-49 years while 25 of them (i.e. about $20.8 \%$ ) were 50 and above. Only 15 of the respondents $(12.5 \%)$ were less than 20 years old (Figure 2). 


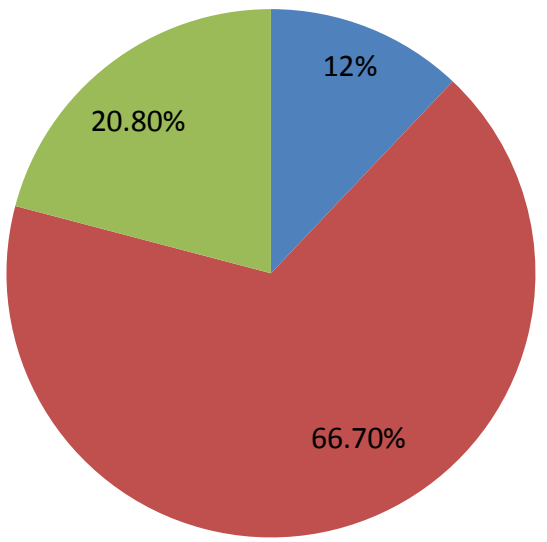

$\square<20$ years old

20-49 years old

$>50$ years old

Figure 2. Age distribution of resondents (source:own survey, 2012).

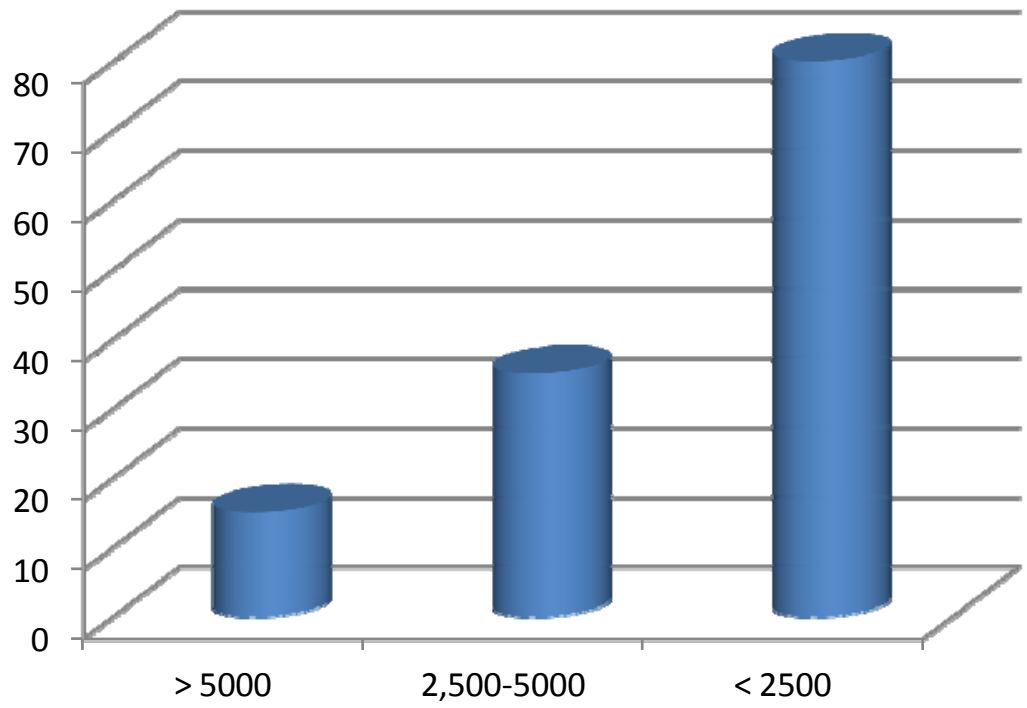

Series1

Figure 3. Income distribution of respondents (Source: own survey, 2012).

\section{Educational status}

Regarding educational status, quite a sizeable proportion of the women, i.e. 85 of the respondents (over 70.8\%) were illiterate, unable to read and write while 30 of the respondents $(25 \%)$ had at least primary education (grades 1-5). An insignificant number, i.e. 4 of them (nearly $3.3 \%$ ) reported they had been exposed to junior or/and senior high school (grades 7-8 and 9-12). Only 1 (about $0.8 \%$ ) reported she had graduated from colleges or university.

With regard to income, the bulk majority (66.6\%) fell within the annual household income of less than 2, 500 birr which is characterized by informants as fairly poor. $29.1 \%$ of the respondents reported an annual household income of 2,500-5, 000 Birr identified by informants as medium status in their local context while only $12.5 \%$ had reported an annual household income of over 5, 000 birr (Figure 3).

The role of education in the management of $\mathrm{PV}$ electricity was assessed by cross tabulating educational status with technical problems of the solar electricity service. The findings revealed that out of the 82 women respondents who experienced problems with PV system, the bulk majority have low educational status. Over $76 \%$ of those women who have had technical PV failures were illiterate indicating that education plays a role in managing solar systems (Table 1).

\section{The relationship between gender and energy}

Empirical studies on the gender-energy nexus have revealed women's significant contribution to the provision 
Table 1. Comparison of $\mathrm{HH}$ educational level with technical PV problems.

\begin{tabular}{lcccccc}
\hline & \multicolumn{3}{c}{ Problem with PV system } \\
\cline { 2 - 7 } Educational Status & \multicolumn{2}{c}{ Yes } & \multicolumn{3}{c}{ No } & \multicolumn{2}{c}{ Total } \\
\cline { 2 - 7 } & No & $\%$ & No & $\%$ & No & $\%$ \\
\hline Illiterate & 63 & 76.8 & 22 & 57.9 & 85 & 70.8 \\
Literate & & & & & & \\
Grades 1-5 & 17 & 20.8 & 13 & 34.2 & 30 & 25 \\
Junior and high & 2 & 2.4 & 2 & 5.3 & 4 & 3.4 \\
College grad. & - & - & 1 & 2.6 & 1 & 0.8 \\
Total & 82 & 100 & 38 & 100 & 120 & 100 \\
\hline
\end{tabular}

(Source: Own survey, 2012).

Table 2. Gender based division of labour in energy supply and other related domestic activities.

\begin{tabular}{lcccccccc}
\hline \multirow{2}{*}{ Members of household } & \multicolumn{7}{c}{ Types of household activities } \\
\cline { 2 - 10 } & \multicolumn{1}{c}{ Firewood } & Wood splitting & Fetching water & Preparing food \\
\cline { 2 - 10 } & No & $\%$ & No & $\%$ & No & $\%$ & No & $\%$ \\
\hline Mother & 46 & 38.3 & 38 & 31.6 & 55 & 45.8 & 99 & 82.5 \\
Father & 29 & 24.2 & 40 & 33.3 & 5 & 4.2 & 2 & 1.7 \\
Daughter & 26 & 21.7 & 20 & 16.7 & 46 & 38.4 & 15 & 12.5 \\
son & 18 & 15 & 18 & 15 & 10 & 8.3 & 2 & 1.7 \\
Neighbors & 0 & 0 & 2 & 1.7 & 3 & 2.5 & 1 & 0.8 \\
Friends & 1 & 0.8 & 2 & 1.7 & 1 & 0.8 & 1 & 0.8 \\
\hline
\end{tabular}

(Source: Own survey, 2012)

of traditional household fuel supply (especially firewood) besides their active role in other domestic chores such as preparing food and fetching water (Wamukonya, 2002). This study also found out that mothers and daughters played the highest role while the contribution from fathers and sons is lower than that of women (Table 2).

As can be seen from Table 2, except in splitting wood in which fathers and sons have significant contribution, much of the household chore is carried out by mothers and daughters. For example, $82.5 \%$ of the respondents indicated that cooking food is carried out by mothers while a significant number (38.3\%) indicated that mothers take the lioness' share in the collection of firewood.

\section{Energy consumption before introduction of solar energy}

PV electricity is now widely being used for lighting, spending time in cooking and baking in several households. An attempt was made to measure the pattern of energy use by women in the selected villages before the introduction of solar energy. The findings indicate that majority of the sampled households (86 \%) used kerosene for lighting. This is followed by dry cell batteries (15\%) and candle (9\%). The use of crop residues and animal dung was also reported by smaller proportion of the sample households. Although a limited proportion of the sampled households still used kerosene and the traditional biomass as a source of energy in addition to PV electricity, much of the energy con-sumption for daily activities comes from solar energy. Key informants argued that solar energy has relieved them from the laborious task of collecting firewood, cow dung, crop residues and other energy sources. The price of kerosene was also reported to be skyrocketing in recent times and hence PV electricity minimized such costs.

As indicated in Table 3, before the introduction of solar energy, the bulk of the power for household consumption came from firewood, kerosene, candle, dung, crop residue and industrially manufactured dry cell batteries. Kerosene, firewood and dry cell batteries were identified as the most costly. Rural women who travelled a long distance to collect fire wood and crop residues and spent many hours wandering in faraway places where they sometimes encounter life threatening experiences. The task of firewood collection, which almost entirely left to women, is very difficult because it often resulted in unprecedented confrontations with guardians of forest areas who demanded some favors from the women. Today forest protection rules have become tougher and women usually remain in nearby areas collecting dry woods in 
Table 3. Pattern of energy consumption before and after the introduction of PV electricity.

\begin{tabular}{lccccccccc}
\hline & \multicolumn{8}{c}{ Energy consumption before and after the introduction of the PV system } \\
\cline { 2 - 11 } Household source of energy & \multicolumn{3}{c}{ Cooking } & \multicolumn{5}{c}{ Lighting } \\
\cline { 2 - 10 } & \multicolumn{3}{c}{ Before } & No & After & Nofore & After \\
\cline { 2 - 10 } & 8 & 6.8 & 7 & 5.8 & 6 & 5 & 0 & 0 \\
\hline Firewood & 7 & 5.8 & 5 & 4.2 & 86 & 71.7 & 6 & 5 \\
Kerosene & 30 & 25 & 29 & 24.2 & 0 & 0 & & \\
Charcoal & 0 & 0 & 0 & 0 & 0 & 0 & 108 & 90 \\
Electricity & 12 & 10 & 12 & 10 & 0 & 0 & & \\
Dung & 7 & 5.8 & 10 & 8.3 & 4 & 3.3 & 0 & 0 \\
Crop residue & 1 & 0.8 & 0 & 0 & 9 & 7.5 & 3 & 2.5 \\
Candle & 1 & 0.8 & 0 & 0 & 15 & 12.5 & 3 & 2.5 \\
Dry cell battery & 54 & 45 & 57 & 47.5 & & & & \\
Combination & 120 & 100 & 120 & & 100 & 100 & \\
Total & & & & & & & 100 \\
\hline
\end{tabular}

(Source: Own survey, 2012).

small quantities. Long distance firewood collection has now become the responsibility of able-bodied young boys and adult men. Women informants reported occasional incidents of sexual harassments and molestations in addition to bites from wild insects. Women suffered from the negative impacts of using traditional sources of fuel as they succumbed to health problems related to eye infections and respiratory diseases. Some women reported that they collect firewood for their own domestic consumption while a significant number of the household heads revealed that they sell firewood and charcoal in small markets to earn money to support their families.

\section{Case 1: W/o Aregash'siii condition}

W/o Weresech Kiros is a 39 years old woman who has lived in Cheli village for many years. She has 5 children currently living with her. Their livelihood depends on cereal farming. Before the advent of solar lighting, she used to depend on kerosene, firewood, cow dung and flashlights to illuminate the house and perform most of the domestic activities such as grinding of cereals, cooking and related tasks. However, she could not work for long hours as she had to economize fuel. She also used to tell her children to go to bed early putting a lot of pressure on their academic work. She explained that during bad years the household income significantly declined to the extent that she was sometimes unable to obtain money for kerosene and hence family members were asked to dine outside with the help of light from firewood. She used to buy a liter of kerosene for 8-9 Birr. She needed about 3 liters of kerosene per month with an overall monthly expenditure of approximately 27 Birr. Today with the PV electricity, she pays only 10-15 birr per month. She spends more time in the evening discharging her domestic responsibilities and her children can now study well without much constraint.

\section{The introduction of solar systems in the study area}

Many women realize that animal dung as a source of energy is competing with its use as an organic fertilizer which is extremely useful to replenish soil fertility ${ }^{i v}$. Women in the study area were generally found to be well aware of the impacts of deforestation. Similarly, they realized that crop residue which is a source of feed for their cattle was being wasted particularly in cooking food. In the study site, the solar energy based PV initiative started in 2008/9 with the help of NGOs and Mekelle University also under the auspices of the Women's Association of Tigrai (WAT). It was reported that this was followed by training of women personnel in India for 6 months. 2 women participated in the training and returned home to serve their communities although one of them has currently left the area possibly in search of better opportunities elsewhere. According to key informants in the Saharti-Samre Wereda administration, close to 1.2 million Birr has been spent to implement the project. The two beneficiary villages (Cheli and Adishishay) were selected on the basis of distance from main grids and topographical features. Currently, there are about 75 household beneficiaries in Cheli village alone. Each household pays 10-15 Birr monthly in order to keep the system running and pay salary of technical experts.

Since solar energy facilities were instituted in the district, a growing number believed PV electricity was a very good replacement for the traditional fuel consumption relieving women from the laborious work of gathering firewood or/and from the more costly use of kerosene, candle and dry cell batteries. However, occasional resort to traditional sources of energy is made even today when 
the need arises. When PV electricity fails adequate power to execute some activities such as cooking and baking, additional energy sources are employed. Other appliances such as refrigerators are too expensive for poor farmers to own but people do not want to take risk trying to apply PV power to run other facilities. There have been several requests especially by the youths to use the power for grinding mills, although there is limited technical knowledge on the level of capacity and how to go about it. Some have already reported that they tried to use PV electricity to operate simple machineries but in vain as it resulted in complete ruin of the instruments because of problems with power adjustment. There is an obvious problem with PV electricity use and management. It was for example reported that of the 98 bulbs that were initially installed in Cheli village 22 went out of order for reasons not even known to the beneficiaries.

\section{Role of solar energy on income generation and access to social services}

The income generation aspect of solar energy is yet to develop in the years to come but there is evidence of small scale investments by women in anticipation of improved access to solar energy facilities for home based commercial activities on a larger scale. Often, the solar power becomes too weak to support bigger appliances for income generation although illumination from PV electricity has given women petty traders the opportunity to attract customers .

The results of the interviews also reveal that the introduction of solar energy systems has enabled women to have more time to actively participate in other productive activities. According to key informants and Focus group discussants the new solar technology has relieved women from spending much of their time in the bush fetching firewood and hence women now have the chance to participate in the rural Safety-net Programmes ${ }^{\text {vi }}$ of the government and earn some income in return for their labour contribution in some development activities such as soil and water conservation and other environmental rehabilitation schemes. Hence, the introduction of solar energy in the villages has put women's attention away from their domestic chores into productive spheres.

Participants of the Focus Group Discussion asserted that access to PV electricity has improved access to social services such as education. Children were able to use their night time for reading and writing assignments or preparing for exams which otherwise would not have been possible in the day time as the post school time is spent on helping parents in domestic activities. Besides, women informants characterized the solar technology a 'smokeless and fireless' venture preventing them from health related problems and possible burns as a result of blazing fire typical of the traditional biomass use. According to key informants from the local administration,
PV electricity has been used to illuminate schools, health posts and training centers as a matter of priority although it is not very well expanded to other service providing institutions because of shortage of supply. Appliances in the health posts (eg. refrigerators) have been powered using PV electricity and information dissemination in schools using mini-media was possible due to such solar systems. Availability of power in the health centers facilitates easy access to medical services with flexible time schedules. In times of emergency, pregnant women can easily be taken to the health center for easy and safe delivery.

According to informants, solar lights have also had a positive impact on their spiritual life. Today even the churches have been well illuminated and hence people in the clergy and their adherents can easily fulfill their religious obligations.

According to informants, solar energy systems, besides other advantages, have indeed facilitated social interactions in their respective villages especially during certain social ceremonies. Other more immediate advantages include preparation of food, entertainments, charging of batteries for mobile phones, etc. As a result, there is a very high demand currently and efforts are being made to scale it up in other villages. It was for example, reported that communities in another village called Gawi have also requested to benefit from the package by contributing about 5,000 Birr in the last couple of years alone and such requests are quickly spreading into other districts and villages - including Bamba, and Esret localities.

\section{Women's attitudes towards solar energy interventions}

As indicate in Table 1 nearly $71 \%$ of the women in the study sites were illiterate and hence can neither read nor write. They also have limited experience and exposure to off-grid energy developments in other areas. When the idea was introduced first, people were skeptical about its positive impact. In fact, many people especially women believed it was also against heavenly order to harvest sun power. Later, such suspicions and attitudes gave way to trust and confidence. Now, having seen the benefits, many women beneficiaries perceive PV based power as a source of pride and confidence which increase their sense of worth. Women saw a huge difference between traditional power sources (eg. kerosene lamps) and PV electricity because the latter provided clearer and brighter light enabling them to carry out their household activities more efficiently.

Women informants identified two types of solar PV apparatuses, which they identified as 'big' and 'small.' While the 'big' ones were said to be more efficient with 24 h service capacity the 'small' ones were characterized as less efficient with only 7-8 $\mathrm{h}$ of lighting per day and were said to be easily liable to malfunctions. While the former 
were installed in strategically important locations, the latter were placed in the peripheries of the villages.

If solar home systems were to be supplied by private enterprises, slight shifts in the attitudes of local community members including women is expected because as Dalelo (ND) has also pointed out there is often a misconception about the private sector (the local term used is negade which literally means merchant) that it is always profit oriented with minimal care for social sustainability.

\section{Challenges and difficulties}

Despite the positive developments in terms of growing demand for solar technologies, there are also challenges hindering the swift diffusion of solar energy technologies into other parts of the Tigrai region. Scaling up of PV technologies into other areas has primarily been hampered by the fact that it is expensive. Farmers, especially poor women household heads find it very difficult not only to purchase essential parts of the solar gadgets but also to keep the system running.

The lack of technical professionals to properly install and repair PV gadgets was also identified by informants as a major problem. Service providers do not often carryout appropriate monitoring of the status of the solar systems when periodic check-ups were needed. Service providers stationed in big cities often lack the courage and motivation to travel to the rural villages for maintenance purposes and those who had some knowledge left the village in search of better opportunities elsewhere.

Informants explained that they too are not equipped with the technical know-how and find it difficult to repair the solar instruments. In fact as most beneficiaries are pre-literate farmers, they are even unable to explain why such solar systems go dysfunctional and could not identify what went wrong when solar systems stop functioning. Spare parts such as fuses are not easily accessible (sometimes not even locally available); and when available, they are often too expensive for beneficiaries. While government and public institutions such as Mekelle University and Women's Association of Tigrai have contributed towards the promotion of solar-energy propelled rural electrification schemes, such initiatives are not being reciprocated by other stakeholders in the private sector.

There is little or no effort so far made by private enterprises to invest in this sector. Local NGOs such as the Relief Society of Tigrai (ReST) and welfare based civil society organizations including the Tigrai Development Association have so far paid little attention to the sector. The local development organizations tend to focus on small scale projects while bigger international companies would probably be interested in quick profit gains. In fact, informants claim that the biggest problem is not the communities' lack of capacity to purchase the service but the lack of interest by local and foreign companies to invest in rural electrification programmes in general and solar energy provision in particular. The result is that there is low level of expansion and rural communities outside the national grid are still without access to electricity. This puts local development potentials at stake and women suffer most from such lack of opportunities. The overall bad image of Ethiopia as poor, famine stricken and the volatility of the Horn of Africa region as a whole might also have had its own impact on why foreign countries have not been effectively gravitated into the country for investment in this sector.

Women informants were asked to prioritize their problems and areas of interventions. With regard to problems, prior focus was made on maintenance problems and demanded regular follow-ups from technical personnel. They suggested that that more and more people from the local community be trained so that they themselves are empowered to run the system on their own. The researcher also observed that installation of PV electricity is far from being gender sensitive as it was randomly assigned to households on the basis of proximity to service giving institutions such as schools and health centers. Such projects should have primarily targeted women headed households and particularly those devoid of adult male labour to fulfill household energy requirements.

\section{Conclusion}

Off-grid power supply through solar energy technologies has been fairly well accepted in Tigrai region and has had multifaceted advantages in recent years. The Solar PV has particularly been beneficial to rural women as an alternative source of energy as it served as an effective substitute for the environment-unfriendly traditional sources of fuel. Before the introduction of the solar systems, firewood collection by poor women exacerbated the scale of deforestation in the areas and consumed a lot of women's time and labour. In addition, it also occasionally exposed them to life threatening hazards in the bushes.

PV electricity supply has improved the quality of life in the study sites. Access to social services such as health and education has improved; a spirit of entrepreneurship flourished and women started to embark on microenterprises for petty trade. Small shops, cafes and traditional drink houses have opened windows of opportunities for income diversification albeit on a limited scale. Besides, the use of information and communication technologies (such as radios, TV and telephones) has enabled women to have access to information especially related to farming, or agriculture in general which is the basis of their livelihoods. Access to market related information also helped women develop awareness on prices of food and non-food items thereby designing their own coping 
strategies. If solar electrification projects could be strengthened further by improving the supply, urbanizetion would possibly serve as a pull factor to gravitate more civil servants into the villages thereby improving the type and quality of service provision in the peripheries.

Despite the aforementioned success stories, solar energy supply and expansion has been constrained by a number of challenges and weaknesses. Firstly, not so many institutions are actively engaged in diffusing solar technologies into the areas in the form of private investment or philanthropy. Secondly, solar technologies need high tech expertise during installation and maintenance. Women especially the household heads were particularly not so economically and technologically empowered to fulfill such demands and were hence unable to sustain the system because of the limited financial power and technical training. Proper expertise and meticulous follow-up mechanisms are therefore currently lacking. Besides, solar energy has hitherto not been efficiently used to support the irrigation sector which is important for agricultural development.

\section{Recommendations}

Generally, rural electrification programmes through solar energy technologies need to be strengthened in the future given their paramount importance in empowering women economically and altering traditional gender relations. As a matter of fact PV electricity is the most viable option for power supply in areas where grid electricity is not reachable due to difficult topography, poor infrastructure and the resultant inaccessibility. Private investors and NGOs need to be encouraged to participate in the process of expanding PV based off-grid power into the rural areas. However, as most poor women could not afford to pay for the system, there should be mechanisms to introduce long term loan services to a wide range of beneficiaries.

Solar energy projects should prioritize beneficiaries to make sure that the poorest of the poor are included in the benefit package. Women headed households should be given special attention in the future as they constitute the bulk of the rural poor in the study area. They should be given adequate and consistent training on the judicious use and management of solar technologies through capacity building workshops and establishing women to women linkages and networking. Besides, local community based organizations should be encouraged to actively participate in facilitating the supply of appropriate technologies (including spare parts) to the needy at an affordable price by establishing appropriate market structures in the neighborhoods. Farmers training centers may also include a package for technology transfer and technical training on solar technology use and maintenance.

Furthermore, the scope of PV based power should be expanded to include utilities other than provision of light to be used in household chores. For example, PV operated water pumps can improve the efficiency of irrigation which is a key instrument to the production of fruits and vegetables particularly by women and hence improve food security status of rural households in general. Finally, functional integration and networking among organizations (government and nongovernmental), each with clearly defined mandate (such as technology supply, training, maintenance, etc.) should be arranged in the future.

\section{REFERENCES}

Afrepren W (2001). African Energy Data Reference Handbook: Volume. IV. Nairobi, Kenya.

Andrade T (2004). Report: Brazil. Enabling urban poor livelihoods policy making: understanding the role of energy services.

Annecke W (1999). From the Kitchen to the Boardroom: Reflections on Power Relations in Gender and Energy Practice and Policy.. Energy and Development Research Centre, University of Cape Town, South Africa: paper presented at the ENERGIA Workshop on Improving Women's Access to Energy, University of Twente, Enschede, the Netherlands.

Baguant J, Manrakhan J (1994). Issues in Energy for the African Region: Higher Education Training with Particular Reference to Mauritius. Working Paper No.20, Nairobi.

Batliwala S, Reddy A (1996). Energy for Women and Women for Energy: A proposal for women's energy entrepreneurship, Energia News 1:11-13.

Burn N, Coche L (2001). Multifunctional Platform for Village Power, in Generating Opportunities: Case Studies on Energy and Women, UNDP, New York. ISBN 92-1-126124-4.

Cecelski E (2004). Rethinking Gender and Energy: Old and New Directions. ENERGIA/EASE Discussion Paper. Available at www.hedon.info access date: December 14, 2011

CSA (Central Statistical Agency) (2008). Summary and statistical Report of the 2007 Population and Housing Census. Federal Democratic Republic of Ethiopia Census Commission Addis Ababa, Ethiopia.

Clancy J (2002). Blowing the smoke out of the kitchen: Gender Issues in Household Energy. Paper prepared for SPARKNET, knowledge network on household energy. Available at: http://www.sparknet.info.

Clancy J (2007). Appropriate Gender-Analysis Tools for Unpacking the Gender-Energy-Poverty Nexus. Gender Dev. 15:2.

Clancy J, Oparaocha S, Roehr G (2004). Gender Equity and Renewable Energies. Thematic Background Paper.

Clancy J, Skutsch M (ND). The Gender-Energy-Poverty Nexus: Finding the energy to address gender concerns in development. Technology and Development Group, University of Twente and Simon Batchelor Gamos Ltd, UK accessed at https://www.esmap.org/sites/esmap.org/files/The\%20Gender\%20Ene rgy\%20Poverty\%20Nexus.pdf access date: October, 2012.

Denton F (2002). Gender: The Missing Link to Energy for Sustainable Development. Policy Paper for World Summit on Sustainable Development, Johannesburg, South Africa.

DFID (Department for International Development) (2002). Energy for the Poor: Underpinning the Millennium Development Goals. Available at http://www.dfid-kar-energy.org.uk/assets/Energy_for_the_Poor.pdf. Access date: January 8, 2012

ECA (Economic Commission for Africa) (2002). Vietnam: the Country and its Rural Electrification Context", October 2002, accessible at http://rru.worldbank.org/Documents/Cam_Lao_Viet_viet.pdf access date: February 2, 2012.

Fagbenle R (2001). Solar Photovoltaics Technologies in Africa. In: Occassional Paper Number 10. African Energy Data and Terminology Handbook. Nairobi: AFREPREN/FWD

Farhar B (2000). Progress on Linking Gender and Sustainable Energy National Renewable Energy Laboratory, USA. 
Gebremedhin B, Pender J, Haile M (2002). Policies for Sustainable Land Management in the Highlands of Tigray, Northern Ethiopia, Summary of papers and proceedings of a workshop Axum Hotel, Mekelle, Ethiopia March 28-29, 2002

Green M (2001). Solar Cookers as a Mechanism for Women's Empowerment, ISES World Solar Congress, Adelaide, Australia.

Heimann S (2009). Renewable Energy in Ethiopia 13 Months of Sunshine for a Sustainable Development, Berlin.

Karekezi S (2002). Renewables in Africa - Poverty Alleviation Instrument First World Renewable Energy Forum: Policies and Strategies. Papers and Documents of the International Conference of the World Council for Renewable Energy.

Karekezi S, Afrepren W (2003). Renewable Energy Development The Workshop for African Energy Experts on Operationalzing the NEPAD Energy Initiative 2- 4 June, 2003.

Karekezi S, Kithyoma W (2002). Renewable Energy Strategies for Rural Africa: is a PV-led renewable energy strategy the right approach for providing modern energy to the rural poor of sub-Saharan Africa? Energy Policy, Vol. 30 Nos. 11-12, Special Issue - Africa: Improving Modern Energy Services for the Poor. Oxford: Elsevier Science Limited.

Karekezi S, Ranja T (1997). Renewable Energy Technologies in Africa. ZED Books and AFREPREN. Oxford U.K.

Karekezi S, Turyareeba P (1995). Renewable Energy Technologies: Mini and Micro Hydro Power in Eastern and Southern Africa, AFREPREN, Nairobi, Kenya. 2:6-8.

Lambrou Y, Piana G (2006). Energy and Gender Issues in Rural Sustainable Development. FAO publication.

Makan A (1995). Power for women and men: Towards a gendered approach to domestic policy and planning in South Africa. Third World Policy Rev. 17(2).

Menash S (2001). Energy for Rural Women's Enterprises, in Generating Opportunities: Case Studies on Energy and Women, UNDP, New York. ISBN 92-1-126124-4.
Schutzeichel H (2012). Ethiopia Solar: Initiation of a solar trade in Ethiopia, 2005-2011, Solar Energy Foundation, GermanySwitzerland- Ethiopia.

Smith K (1999). Indoor Air Pollution: Pollution Management in Focus, Discussion Note No. 4, August 1999. World Bank, Washington.

Smith K (2002). In praise of petroleum? Science 298 (5600): 1847. Available at http://www.sciencemag.org/cgi/reprint/298/5600/1847.pdf access date: December 14, 2011.

Tigray Regional State (2010). Five Years (2010/11 - 2014/15) Growth \& Transformation Plan. Bureau of Plan and Finance.

Ward R, Ashworth J, Burril G (1984). Renewable Energy Technologies in Africa: An Assessment of Field Experience and Future Directions. Bureau for Africa/Agency for International Development. Washington.

World Bank (2003). Household Fuel and Energy Use in Developing Countries- Amulti country Study accessible at http://www.esmap.org/sites/esmap.org/files/Report_FuelUseMulticou ntryStudy_05.pdf access date: January 8, 2012.

World Bank (2004). Global Monitoring Report: Policies and Actions for Achieving the Millennium Development Goals and Related Outcomes. World Bank: Washington, DC, USA. 
${ }^{1}$ Tabia is an administrative unit below the Wereda and above the Kushet levels. In this paper the English words district and village have been used to denote Wereda and Tabia respectively

${ }^{\text {ii }}$ The following table shows the questionnaire items and concept measured.

\begin{tabular}{|c|c|c|c|}
\hline No & Core Questionnaire items & $\begin{array}{l}\text { Concepts } \\
\text { measured }\end{array}$ & remark \\
\hline 1 & $\begin{array}{l}\text { Describe the division of } \\
\text { labour in the household } \\
\text { (what is the role of men, } \\
\text { women and children in the } \\
\text { household?) }\end{array}$ & $\begin{array}{l}\text { Gender relations } \\
\text { in energy supply }\end{array}$ & $\begin{array}{l}\text { The questionnaire } \\
\text { items have been } \\
\text { abridged to fit the } \\
\text { purpose of brevity }\end{array}$ \\
\hline 2 & $\begin{array}{l}\text { Explain the source of fuel } \\
\text { for the household before } \\
\text { and after the introduction } \\
\text { PV electricity? }\end{array}$ & $\begin{array}{l}\text { Household energy } \\
\text { consumption } \\
\text { pattern across } \\
\text { time }\end{array}$ & \\
\hline 3 & $\begin{array}{l}\text { Has the livelihood of the } \\
\text { household improve after the } \\
\text { introduction of PV } \\
\text { electricity? }\end{array}$ & $\begin{array}{l}\text { Women's access } \\
\text { to income }\end{array}$ & \\
\hline 4 & $\begin{array}{l}\text { Has the introduction of PV } \\
\text { electricity improved your } \\
\text { relationships with other } \\
\text { people? How? }\end{array}$ & $\begin{array}{l}\text { Impacts of solar } \\
\text { system on family } \\
\text { relations and } \\
\text { socialization }\end{array}$ & \\
\hline 5 & $\begin{array}{l}\text { Has the introduction of PV } \\
\text { electricity helped people in } \\
\text { sending children to school? }\end{array}$ & $\begin{array}{l}\text { Access } \\
\text { education }\end{array}$ & \\
\hline 6 & $\begin{array}{l}\text { IS PV electricity being used } \\
\text { in the clinics? How? }\end{array}$ & $\begin{array}{l}\text { Access to social } \\
\text { services }\end{array}$ & \\
\hline 7 & $\begin{array}{l}\text { What are the problems } \\
\text { associated with PV } \\
\text { electricity? }\end{array}$ & $\begin{array}{l}\text { The challenges of } \\
\text { the Solar system }\end{array}$ & \\
\hline 7 & $\begin{array}{l}\text { Do you think } \\
\begin{array}{l}\text { the } \\
\text { introduction of }\end{array} \\
\text { electricity was a good } \\
\text { initiative? }\end{array}$ & $\begin{array}{l}\text { Women's overall } \\
\text { attitudes on the } \\
\text { solar energy } \\
\text { initiative }\end{array}$ & \\
\hline
\end{tabular}

${ }^{3}$ All personal names appearing in this paper are fake. True names are concealed for the sake of privacy

${ }^{4}$ Focus group discussants underscored the role of organic manure in soil fertility management especially in light of the mounting prices of industrially manufactured fertilizers supplied by the bureau of agriculture and rural development and cooperatives. However, since most of the rural people are poor, there aren't enough number of cattle to provide adequate manure for the agricultural fields.

${ }^{5}$ The fact that Cheli is not found on the main road connecting districts or subdistricts has actually discouraged people including women from starting up small business ventures as the mobility of people is constrained by the lack of transport facilities.

${ }^{6}$ Safety net programmes in the study sites take the form of productive and direct support packages. Only those who cannot contribute labour(eg. the elderly and the handicapped) can benefit from direct support programmes. 